\title{
MICROBIAL CONTAMINATION OF CHICKEN CARCASSES DURING SLAUGHTERING PROCESS IN KHARTOUM STATE, SUDAN
}

\author{
G.A.K. GABEER*; S.E. SULIMAN*; A. GHALI** and M.A. ABDALLA* \\ * College of Veterinary Medicine, Sudan University of Science and Technology. \\ ** Veterinary Research Institute, Soba, Khartoum, Sudan.
}

\begin{tabular}{ll}
\hline ABSTRACT \\
\hline A total of 75 swab samples were collected randomly from chicken carcasses slaughtered at \\
modern poultry abattoir in Khartoum state, Sudan. These samples were taken from 5 \\
operational processing, after defeathering, after evisceration, after spray first washing, after \\
spray second washing and after chilling. Also 75 swab samples were collected from workers \\
hands. Total viable count (TVCs) was carried for each samples and also isolation and \\
identification of contaminated bacteria. The study revealed that statistical significant \\
difference (p<0.05) in 5 operations when the samples were taken from the legs, backs and \\
breast sites respectively. There was no statistical significant difference (p $>0.05)$ when the \\
TVCs used from workers hands. The types of bacteria isolated were E. coli and Salmonella \\
spp. Sudanese abattoirs may reflect the hygienic status of chicken meat production in the \\
developing countries.
\end{tabular}

Key words:

\section{INTRODUCTION}

Poultry was an important part of the animal food market and production, it was increasing to satisfy public demand world-wide (Bryan 1980; Anand et al., 1989).

However, broilers entering slaughter processing are highly contaminated by microorganisms, including food borne pathogens such as Salmonella and Campylobacter spp., and these pathogens tend to be disseminated in the processing (Mead et al., 1994).

The micro-organisms were widely distributed over the carcasses under normal circumstances and were spread over the skin during scalding and defeathering and on the inner and outer surfaces during evisceration and further processing (Bailey et al., 1987).

The procedure for converting a live, healthy bird into a safe and wholesome poultry product provided many opportunities for micro-organisms to colonize on the surface of the carcasses (Bryan, 1980; Thomas and McMeekin., 1980; Roberts, 1982; Grau, 1986; Bailey et al., 1987; Connor et al., 1987; Banwart, 1989; Mead, 1989).

Poultry processing had a number of unique features which make control of microbial contamination more difficult than the processing of any other conventional meat animal. Among them was the rapid rate of processing in some processing plants, a condition which favoured the spread of micro-organisms. The carcass must be kept whole throughout the process and the viscera have to be removed rapidly through a small opening in the abdomen without breakage, to minimize contamination of the carcass with intestinal organisms. After defeathering, the skin provided a complex surface with many holes which were capable of trapping bacteria (Mead, 1982; Grau, 1986; Mead, 1989). In the Sudan broiler chickens population was estimated to be 22.5 million chicks. Traditional sector (small farms) produced about $60 \%$ of the total broiler production and the modern sector (companies) produced the rest (Ministry of Animal Resources and Fisheries (MARF), 2008). Microbiological status of broiler carcasses depends on several factors, such as: infection level of living birds and/or cross contamination during processing (Abu- Ruwaida et al., 1994).

The purpose of this study was to investigate the contamination level of chicken carcasses during slaughtering processing at modern abattoir in Khartoum state.

\section{MATERIALS and METHODS}

The study was conducted in Khartoum state, Sudan. A total of 75 swab samples were collected randomly from modern poultry abattoir. These samples were taken from 5 operational processing points, after defeathering, after evisceration, after spray first washing, after spray second washing, and after chilling. Also 75 samples were taken from worker hands. The collection of the samples were carried out every one week, on the surface of the carcasses at three sites leg, back and breast and the duration of collection over a period of two months. A sterile metal template of $10 \mathrm{~cm}^{2}$ area was used to outline the swabbing area on the broiler carcasses the area was swabbed vigorously with sterile swab. The organisms were removed from each swab by shaking for few minutes in $10 \mathrm{ml}$ of sterile $0.5 \%$ peptone water. The method that used as described by Harrigan, (1976) for total viable count (TVC). Isolation and identification 
of the bacteria was carried by prepared nutrient agar, nutrient broth, MacConkeys agar (MCA) and Blood Agar. The plates were incubated at $37^{\circ} \mathrm{C}$ for $24 \mathrm{hrs}$. Well isolated colonies obtained from agar medium and different broth cultures of Gram-negative and Gram-positive bacteria were constantly subcultured into agar slants from time to time, incubated at $37^{\circ} \mathrm{C}$ for $24 \mathrm{hrs}$ and stored at $4^{\circ} \mathrm{C}$. Identification was based mainly on the biochemical test according to Barrow and Feltham, (1993).

\section{Statistical Analysis}

The data were analyzed with SPSS software (Statistical Package for the Social Sciences, version 11.5, SSPS Inc, and Chicago, IL, USA). All bacterial counts were converted to $\log _{10} \mathrm{CFU} / \mathrm{cm}^{-2}$ for analysis and ANOVA was performed. Statistical significance was set at a $P$ value of $<0.05$.

\section{RESULTS}

The mean total viable counts of the 75 swabs samples from chicken carcasses, in defeathering operation were $7.69 \pm 2.6,7.49 \pm 1.6$ and $8.38 \pm 2.1 \log 10 \mathrm{CFU} \mathrm{cm}^{-}$ 2 at legs, backs and breast sites, respectively, with statistical significant differences $(\mathrm{p}<0.05)$. Also in evisceration point the TVCs were, $7.60 \pm 2.8,7.80 \pm 2.7$ and $8.80 \pm 2.4 \log _{10} \mathrm{CFU} \mathrm{cm} \mathrm{cm}^{-2}$ at the three sites with statistical significant differences $(\mathrm{p}<0.05)$. In point after spray first washing, TVC were $8.30 \pm 1.9$, $6.09 \pm 1.9$ and $6.4 \pm 1.1 \log _{10} \mathrm{CFU} \mathrm{cm} \mathrm{cm}^{-2}$, whereas, in after spray second washing the TVCs were $4.1 \pm 1.07$, $2.6 \pm 1.2$ and $3.2 \pm 1.01 \log _{10} \mathrm{CFU} \mathrm{cm} \mathrm{cm}^{-2}$, in legs, backs and breast sites, respectively with statistical significant differences $(\mathrm{p}<0.05)$. But after chilling operation the mean the TVCs were $1.7 \pm 0.71,1.9 \pm 0.72$ and $1.8 \pm 0.70 \log _{10} \mathrm{CFU} \mathrm{cm} \mathrm{cm}^{-2}$ in legs, backs and breast sites, respectively with statistical significant differences $(\mathrm{p}<0.05)$. The TVCs from workers hands were $1.3 \pm 0.02$ and $1.4 \pm 0.01 \log _{10} \mathrm{CFU} \mathrm{cm} \mathrm{cm}^{-2}$ in the legs and breast sites respectively, with insignificant difference $(\mathrm{p}>0.05)$ (Table 1).

Table 1: Camparison of mean total viable count of bacteria $\left(\log _{10} \mathrm{CFU} \mathrm{cm} \mathrm{cm}^{-2}\right) \pm \mathrm{Sd}$ at different operational points at different sites on chicken carcasses.

\begin{tabular}{|c|c|c|c|c|}
\hline Operation & Legs & Backs & Breast & Significance \\
\hline \multicolumn{5}{|l|}{ Site } \\
\hline After defeathering & $7.69 \pm 2.6$ & $7.49 \pm 1.6$ & $8.38 \pm 2.1$ & $*$ \\
\hline After evisceration & $7.60 \pm 2.8$ & $7.80 \pm 2.7$ & $8.80 \pm 2.4$ & $*$ \\
\hline After spray first washing & $8.30 \pm 1.9$ & $6.09 \pm 1.9$ & $6.40 \pm 1.1$ & $*$ \\
\hline After spray second washing & $4.10 \pm 1.07$ & $2.60 \pm 1.2$ & $3.20 \pm 1.01$ & $*$ \\
\hline After chilling & $1.70 \pm 0.71$ & $1.90 \pm 0.72$ & $1.80 \pm 0.70$ & $*$ \\
\hline Workers hands & $1.30 \pm 0.02$ & N.D & $1.40 \pm 0.01$ & N.S \\
\hline
\end{tabular}

* significant difference at level $(\mathrm{P}<0.05)$; N.D. not done and N.S. Not significant $(\mathrm{P}>0.05)$

This study revealed two species of bacteria isolated from total of 114 samples of chicken carcasses and these were E.coli and Salmonella spp. E,coli was isolated in all operational points After Defeathering, After Evisceration, After spray first washing, After spray second washing and After chilling, whereas Salmonella spp. was isolated in two operational process After Evisceration and After spray first washing. (Table 2)

Table 2: Incidence of E.coli and salmonella spp. Isolated from chicken carcasses in different operational points.

\begin{tabular}{lcccc}
\hline Different & \multicolumn{3}{c}{ E.coli } & \multicolumn{2}{c}{ Salmonella spp. } \\
\cline { 2 - 5 } operational points & No. & $\%$ & No. & - \\
\hline After defeathering & 20 & 17.54 & 7 & 6.14 \\
\hline After Evisceration & 23 & 20.18 & 6 & 5.26 \\
\hline $\begin{array}{l}\text { After spray } \\
\text { washing 1 }\end{array}$ & 21 & 18.43 & - & - \\
\hline $\begin{array}{l}\text { After spray } \\
\text { washing 2 }\end{array}$ & 19 & 16.67 & & - \\
\hline After chilling & 18 & 15.78 & - & - \\
\hline
\end{tabular}

\section{DISCUSSION}

It is obvious that the variability in microbial counts (especially after washing) indicate the need for use of prerequisite programs. The reduction of the microbial contamination in this study (Table 1) is in agreement with Rahkio and Korkeala (1996) who said that the enforcement of hygienic practice such as regular disinfection of working tools and worker hands is important in reducing the microbiological contamination of carcasses. John et al. (2000) reported that the reduction of bacterial contamination during slaughtering after using a degree of sanitation.

Another study by Jeffery et al. (2003) revealed that the workers hands and the equipments were the sources of meat contamination; these results are in accordance with 
the present results. The elimination of contamination sources by practicing good sanitary measures will reduce the occurrence of microorganisms. Appropriate methods should be applied during slaughtering operations, using adequate water and disinfection. Such control measures should include an extensive education programs for proper hygiene and improvement of managements.

Both methods trimming and washing for reducing contamination can be applied, aiming to the use of chicken for cutting and processing. So, immersion pre-chilling system is the determinant to the decreasing of number of microorganisms, as long as it is following all legislation requirements. If the chicken carcass is only washed without the trimming it can be commercialized intact with quality assurance. Economically, to keep the carcasses with skin is more interesting for the company.

Sudan is a tropical country, with ambient temperatures conducive for the growth of microorganisms, which can rapidly render meat unsafe for human consumption. The levels of microbial contamination in Sudanese abattoirs may reflect the hygienic status of poultry meat production in the developing world.

The microbial count on either the carcass depends on various factors. These are the initial count on carcasses, the ambient temperatures, personal hygiene, the efficiency of applied sanitary programmes. Beside changes in the water supply and quality, levels of cleaning of the carcass surface and the general management procedures applied throughout the carcass production (Nortije et al., 1990).

From public health point of view, the most elaborate hygienic precautions in the slaughterhouse can largely be modified by subsequent poor handling of the meat. Little or no control anywhere along the lines i.e. slaughterhouse, Market and restaurant, usually means the onset of a human disease (Ahmed, 2004).

Qualitative bacterial examination of carcass samples in this study revealed Salmonella spp. and Escherichia coli isolated at different stages of carcass preparation; in skinning and evisceration, chilling and after the washing point. Sites selected for sampling included those most favoured by the consumers i.e. the flank, Shoulder and hind leg. Slaughterhouse personnel were also included where their knives checked for aerobic bacterial presence (Ahmed, 2004).

The presence of Escherichia coli as a contaminant of fresh meat which is reported here has also been reported by several workers. Omer (1990) and Ahmed (2004) suggested faecal contamination as a cause of the large numbers of isolates of $E$. coli they recovered. The isolation of bacteria from workers in this study, and the presence of E. coli in fresh meat can be attributed to carcass contaminated with the gastrointestinal contents during the processing.

An important observation in the present study is that Salmonella spp. was isolated from the samples examined. This is in contrast with the result of Ahmed (2004). The highest contamination levels recorded in the point of washing in all sites (flank, Hind leg and Shoulder) may be due to unclean management during the washing, this is in agreement with (Ali, 2007) who reported the highest level of contamination with regard to the critical control point was found in washing point.

\section{REFERENCES}

Abu-Ruwaida, A.S.; Sawaya, W.N.; Pashti, B.H.; Murad, L. and AL-Ahmed, K.K. (2004): Meat hygiene Assessment in a slaughter house in Khartoum State. M.V.Sc. Thesis University of Khartoum Sudan.

Ali, A.A. (2007): Prevalence of bacterial contamination of public health concern on bovine carcasses at Khartoum state - Sudan. M.V.Sc. Thesis Sudan University of Science and Technology, Sudan.

Anand, S.K. and Mahapatra, C.M.; Pandey, N.K. and Verma, S.S. (1989): Microbiological Changes on Chicken Carcasses During Processing. Indian Journal of Poultry Science. 24: (3) 203-209.

Bailey, J.S.; Thomson, J.E. and Cox, N.A. (1987): Contamination of poultry during processing. [Edited by Cunningham F.E. and N.A. Cox] In The microbiology of poultry meat products. Academic Press, Orlando. 193-211.

Banwart, G.J. (1989): Basic food microbiology. $2^{\text {nd }} \mathrm{ed.}$ Published by Van Nostrand Reinhold.

Barrow, G.I. and Feltham, R.K.A. (1993): Manual for the identification of medical bacteria $\left(3^{\text {rd }}\right.$ ed $)$. Cambridge University Press, Cambridge.

Bryan, F.L. (1980): Poultry and meat products. [Edited by Silliker J.H., Elliot R.P., Baird- Parker A.C., Bryan F.L., Christian J.H.B., Clark D.S., Olson J.C. and T.A. Roberts] In Microbial Ecology of Foods, Vol.2: Food Commodities. (ICMSF) 410458.

Connor, J.T.; McMeekin, T.A. and Patterson, J.T. (1987): Prevention of microbial contamination in the poultry processing plant. [Edited by Smulders F.J.M.] In Elimination of Pathogenic Organisms from Meat and Poultry. Proceedings of the International Symposium: Prevention of Contamination, and Decontamination in the Meat Industry. Zeist, the Netherlands, 2-4 June (1986). Elsevier Science Publishers. 163-168.

Grau, F.H. (1986): Microbial ecology of meat and poultry In Advances in Meat Research, [Edited by Pearson A.M. and T.R. Dutson] Vol.2: Meat and Poultry Microbiology. Avi Publishing Company, Inc. 1-36.

Harrigan, W.F. and MacCance, M.E. (1976): Laboratory Methods in food and Diary Microbiology. Academic Press New York .pp. 45-48. 
Jeffery, B.; Donald, AB. and Gill, CO. (2003): Implementation of validated HACCP system for the control of microbiological contamination of pig carcass at a small abattoir. Can. Vet. J. 44: 1.

John, M.; McEvoy, Alice MD.; James, J. and Sheridan, MA. (2000): Contamination of beef carcasses during hide removal and use of a test bacterial decontamination system on beef hide The National Food Centre Teagasc, Dunsinea, Castleknock, Dublin pp. 11-15.

Mead, G.C. (1982): Microbiology of poultry and game birds. [Edited by Brown M.H.] In Meat Microbiology. Applied Science Publishers Ltd. 26-27.

Mead, G.C. (1989): Hygiene problems and control of process contamination. [Edited by Mead G.C.] In Processing of Poultry. Elsevier Science Publishers Ltd. 183-220.

Mead, G.C.; Hudson, W.R. and Hiton, M.H. (1994): Use of a marker organism in poultry processing to identify sites of crosscontamination and evaluate possible measures. Br. Poultry. Sci. 9-12.
Ministry of Animal Resources and Fisheries (2008): Statistical year book. Central Beareau of Statistic, Agriculture center, Khartoum. Sudan: 101-142. http://cbs.gov.sd/pub.htm

Nortije, G.L.; Jordaan, E.; Badenhorst, K.; Goedhart, G.; Hozapfel, W.H. and Grimbeek, R.J. (1990): The influence of incubation temperature on bacterial count in a meat production system $\mathrm{J}$. of Food Protec., 53: 418-422.

Omer, E-F.E-O. (1990): "Review of Medical Bacteriology " First ed. Sudan).

Rahkio, M. and Korkeala, H. (1996): Microbiological contamination of carcasses related to hygiene practice and facilities on slaughtering lines. Acta. Vet. Scand.; 37(3): 219-28.

Roberts, D. (1982): Bacteria of public health significance In Meat Microbiology. [Edited by Brown M.H.]. Applied Science Publishers Ltd. 319-386.

Thomas, C.J. and McMeekin, T.A. (1980): Contamination of broiler carcass skin during commercial processing procedures: an Electron microscopy Study. Applied and Environmental Microbiology 40(1): 133-144.

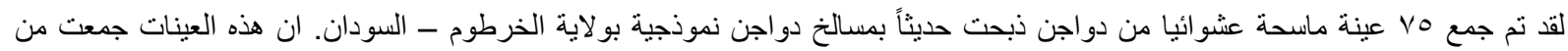

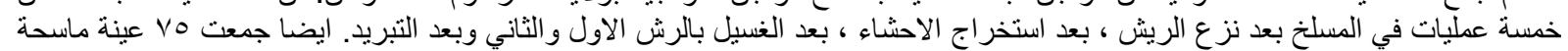

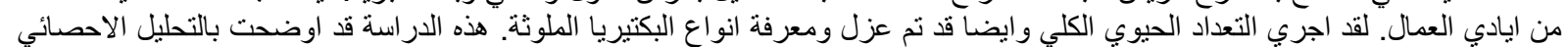

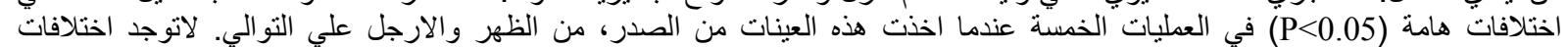

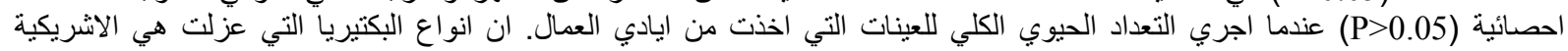
القولونية وانواع السالمونيلا. ان المسالخ السودانية تعكس الحالة الصحية لانتاج لحوم الو أجن في الدول النيات النامية.
} 